\title{
Zastosowanie metody Sheparda do szacowania nieruchomości
}

\begin{abstract}
Rafat Zbyrowski*
Celem badania jest ocena przydatności metody interpolacji Sheparda do szybkiego wspomagania wyceny nieruchomości mieszkaniowych $w$ Warszawie. W świetle zaprezentowanej analizy empirycznej można sformutować następujaca hipotezę badawczą: metoda Sheparda pozwala w sposób zautomatyzowany szacować wartość nieruchomości mieszkaniowych na podstawie jej wtasności interpolacyjnych, stanowiąc interesujące narzędzie wspomagające prace ekspertów od wyceny nieruchomości. Metoda interpolacji Sheparda zostata pierwotnie stworzona do opisu zmiennych $w$ przestrzeni dwuwymiarowej. Stad $w$ analizie empirycznej postużono się przyktadem oszacowania wartości mieszkań dla dzielnicy Biatotęka, $w$ której dominujace znaczenie posiadaja dwie zmienne, tj. liczba metrów kwadratowych i liczba lat budynku. Przyktad zastosowania wyceny na podstawie metody Sheparda zostat skonfrontowany $z$ oszacowaniami modelu regresji liniowej. Ponadto $w$ opracowaniu poruszono kwestie zwiazane $z$ trudnościami procesu wyceny mieszkań $w$ kontekście oddziatywania procesów mikro i makroekonomicznych.
\end{abstract}

Słowa kluczowe: rynek nieruchomości, mieszkalnictwo, modelowanie na rynku nieruchomości, szacowanie i wycena mieszkań.

Nadesłany: 19.12.2016 | Zaakceptowany do druku: 28.12.2016

\section{The Application of the Shepard's Interpolation for a Property Valuation}

The main purpose of this paper is an application of Shepard's interpolation method in valuing flats in Warsaw. This method was originally invented for a two-dimensional interpolation. Therefore the aplication is based on district "Biatoteka", where the major issues are a number of square meters and age of building. The case of the application of Shepard's interpolation method to a database on "Biatoteka" is compared to a classic linear regression model. This article also describes the background of valuing real estates using automatic or mathematical methods in the conclusions. These quantitative methods may be very useful for experts as a fast support. Anyway the experts should be aware of its adventages and disadventages. The market in Poland is shaped by many micro- and macroeconomic processes, hence valuing is a challenge even for experts.

Keywords: real estate, housing, models and applications, valuating.

Submitted: 19.12.2016 | Accepted: 28.12.2016

JEL: R30, R31, E37

\footnotetext{
Rafał Zbyrowski - dr, Zakład Badań Operacyjnych Zarządzania, Wydział Zarządzania, Uniwersytet Warszawski.

Adres do korespondencji: Zakład Badań Operacyjnych Zarządzania, Wydział Zarządzania, Uniwersytet Warszawski, ul. Szturmowa 1/3, 02-678 Warszawa; e-mail: Rzbyrowski@wz.uw.edu.pl.
} 


\section{Wprowadzenie}

Zarówno decyzje licencjonowanych rzeczoznawców majątkowych, jak i symulacje numeryczne wymagaja dostępu do zbioru aktualnych informacji o nieruchomościach podobnych (Nurek, 2004). Próba badawcza została pozyskana dzięki współpracy autora z jedną z działających na terenie Warszawy agencji obrotu nieruchomościami. Obejmuje ona nieruchomości mieszkaniowe (dokładnie 72 obiekty), zlokalizowane w obrębie dzielnicy Białołęka, które trafiły do ofert sprzedaży w 2009 roku. Obiekty stanowiące próbę zostały scharakteryzowane za pomoca trzech fundamentalnych cech. tj. całkowitej ceny ofertowej, powierzchni i liczby lat. $\mathrm{Na}$ podstawie wymienionych cech stworzono trzy zmienne badawcze, których podstawowe statystyki opisowe przedstawia tabela 1.

Próba zawiera nieruchomości mieszkaniowe o przeciętnym standardzie, których powierzchnia użytkowa waha się pomiędzy 31 a 90 metrów kwadratowych. Do niniejszej bazy danych trafiły wyłącznie mieszkania z rynku wtórnego o liczbie lat z zakresu 4-29. W badaniu nie uwzględniono apartamentów, obiektów o podwyższonym standardzie, których powierzchnia mieszkalna przekraczała znacznie 100 metrów kwadratowych. Celowe usuniecie mieszkań wyjąt- kowo dużych i luksusowych było podyktowane chęcią pracy na danych dotyczących mieszkań względnie homogenicznych pod wzglądem standardu. Dzielnica Białołęka charakteryzuje sie przewaga dość młodej zabudowy. Należy jednak pamiętać, że okres, z którego pochodzi próba badawcza był niestabilny gospodarczo, co było związane z ogólnoświatowym kryzysem. Wyceny dokonywane w 2009 roku były obarczone dużym marginesem błędu $\mathrm{z}$ uwagi na niewielką liczbę transakcji na rynku (Baranowski, 2009).

\section{Metoda badawcza}

Analiza empiryczna została przeprowadzona na podstawie metody interpolacji zaproponowanej w 1968 roku przez Donalda Sheparda, która jest wzorowana na wzorze interpolacyjnym Lagrange'a (Kincaid i Cheney, 2002). Jest to metoda bardzo ogólna z matematycznego punktu widzenia $\mathrm{z}$ podprzestrzenia dobierana do $\mathrm{n}$ różnych węzłów $z_{k}=\left(x_{k}, y_{k}\right)$ gdzie $1 \leq k \leq N$. Metoda znajduje zastosowanie do aproksymacji wartości funkcji w dowolnych punktach na podstawie zbioru wartości funkcji w $\mathrm{N}$ nieregularnie rozmieszczonych punktach. Początkowo metoda zaproponowana była przez jej autora do zastosowania w wielu dziedzinach, które wykorzystują

Tabela 1. Statystyki opisowe zmiennych zastosowanych w badaniu

\begin{tabular}{|l|c|c|c|}
\hline & Cena & Powierzchnia & Liczba lat \\
\hline Średnia & 383701,90 & 51,73 & 8,26 \\
\hline Błąd standardowy & 11373,75 & 1,71 & 0,51 \\
\hline Mediana & 373000 & 51,5 & 7 \\
\hline Dominanta & 414000 & 54 & 6 \\
\hline Odchylenie standardowe & 96509,44 & 14,52 & 4,30 \\
\hline Wariancja próbki & 9314071645,5 & 210,96 & 18,45 \\
\hline Kurtoza & 0,02 & $-0,48$ & 9,80 \\
\hline Skośność & 0,58 & 0,51 & 2,84 \\
\hline Zakres & 409400 & 59 & 25 \\
\hline Minimum & 222600 & 31 & 4 \\
\hline Maksimum & 632000 & 90 & 29 \\
\hline Suma & 27626537 & 3724,7 & 595 \\
\hline Liczba obserwacji & 72 & 72 & 72 \\
\hline
\end{tabular}

Źródło: opracowanie własne. 
dane empiryczne związane $\mathrm{z}$ powierzchnią (Shepard, 1968). Wówczas pojawia się zapotrzebowanie na interpolację $\mathrm{z}$ nieregularnie rozmieszczonych danych, z czym wiąże się uzyskanie ciągłej powierzchni. Nieregularnie rozmieszczone dane zwane „węzłami” spotyka się w wielu praktycznych zastosowaniach związanych z obserwacja pogody, geografia, w badaniach ankietowych, w zagospodarowaniu przestrzennym i biologii. W przypadku takich zastosowań zakłada się, że unikalna wartość (np. opadów w meteorologii lub wysokości w geografii) jest powiązana $\mathrm{z}$ określonym węzłem (punktem danych, tj. „data point”). Za pomocą metody Sheparda można dopasować np. do danych geograficznych funkcję, która pozwala dokonać wizualizacji zbioru danych empirycznych w perspektywie. Możliwe staje się wyświetlanie danych w postaci mapy, która pomaga analizować skrajności i dokonywać porównań. Proces interpolowania w tej metodzie zakłada, że oryginalne dane nie są obarczone błędem lub kompensacja błędu zostanie dokonana dopiero po interpolacji.

W tzw. przypadku dwuwymiarowym aproksymacja Sheparda jest najbardziej intuicyjna. Baza danych zawiera $\mathrm{N}$ punktów o współrzędnych $\left(x_{k}, y_{k}\right)$, dla których znane są wartości $z_{k}$ oraz $k$ zmienia się w przedziale $1 \leq k \leq N$. Wówczas aproksymowane wartości funkcji ,z" dla dowolnych argumentów $(x, y)$ można obliczyć w następujący sposób (Shepard 1968):

$\operatorname{gdy} x=x_{k}$ i $y=\mathrm{y}_{k}$ to $\operatorname{gdy} z(x, y)=z_{k}$, w pozostałych przypadkach:

$$
z(x, y)=\frac{\sum_{k=1}^{N} w_{k}(x, y) z_{k}}{\sum_{k=1}^{N} w_{k}(x, y)}
$$

oraz $w(x, y)$ oznacza funkcję wag daną wzorem:

$$
w_{k}(x, y)=\frac{1}{\left(\sqrt{\left(x-x_{k}\right)^{2}+\left(y-y_{k}\right)^{2}}\right)^{P}}
$$

$$
\text { gdzie najczęściej } \mathrm{P}=2 \text {. }
$$

Pierwotnie D. Shepard rekomendowal swoją metodę interpolacji jako właściwą w przypadku funkcji dwóch zmiennych, gdzie współrzędne x i y mogą odpowiadać rozmieszczeniu na mapie (siatce). Metoda w wersji ogólnej może być jednak zastosowana również dla przypadku przestrzeni wielowymiarowej (Gordon, Wixom, 1978).

\section{Wyniki badań empirycznych}

Analizie empirycznej poddano ceny nieruchomości mieszkaniowych w obrębie dzielnicy Białołęka w Warszawie z 2009 roku. Ceny stanowią wartość funkcji z dla punktów empirycznych x i y. „Węzły” o współrzędnych $(x, y)$ tym razem nie reprezentują położenia na mapie, ale odpowiadają następującym charakterystykom badanych obiektów:

$\mathrm{x}$ - powierzchnia mieszkania $\mathrm{w}$ metrach kwadratowych;

y - liczba lat obiektu liczona od roku oddania do użytku.

Naturalnie do wyjaśnienia numerycznego tak złożonej kategorii, jaką jest wartość nieruchomości mieszkaniowej konieczne jest w praktyce uwzględnienie wielu jego charakterystyk. Dostep to szerokich i zarazem aktualnych źródeł informacji o nieruchomościach jest warunkiem koniecznym prowadzenia szacunków o wymiarze praktycznym. Autor niniejszego opracowania, ze względu na swój ograniczony dostęp do danych liczbowych, skoncentrował się jedynie do aproksymacji wartości funkcji dwóch zmiennych metodą Sheparda dla dzielnicy Białołęka. Z wcześniejszych badań przeprowadzonych przez autora wynika jednak, że dzielnica ta odznacza się pewną specyfiką, która sprawia, że $z$ punktu widzenia analiz ilościowych właśnie liczba lat budynku obok powierzchni danej nieruchomości mieszkaniowej jest tutaj najważniejszym wyznacznikiem wartości. Nie wymaga komentarza fakt, że we wszystkich dzielnicach Warszawy podstawową charakterystyką szacowanego mieszkania jest powierzchnia, aczkolwiek Białołęka wykazuje wyjatkowo silne skorelowanie ceny wyłącznie $\mathrm{z}$ powierzchnią lokalu i latami budynku.

Tabela 2 zawiera zestawienie dwudziestu hipotetycznych szacunków nieruchomości mieszkaniowych wykonanych za pomoca regresji liniowej i metody Sheparda dla zadanych wartości powierzchni i liczby lat (gdzie $z(x, y)$ oznacza aproksymowaną wartość funkcji). Zestaw danych testowych został tak dobrany, aby zawierał zarówno obiekty o powierzchni małej, średniej, jak i relatywnie dużej w zakresie badanej próby. 
Tabela 2. Porównanie oszacowania wartości nieruchomości mieszkaniowej na podstawie regresji liniowej i metody interpolacji Sheparda

\begin{tabular}{|c|c|c|c|}
\hline Regresja & $\mathbf{Z}(\mathbf{x}, \mathbf{y})$ & $\mathbf{X}\left[\mathrm{m}^{2}\right]$ & $\mathbf{Y}[$ lata $]$ \\
\hline 285227 & 278638 & 35 & 7 \\
\hline 283209 & 279845 & 33 & 4 \\
\hline 287947 & 298060 & 36 & 8 \\
\hline 294091 & 310364 & 37 & 8 \\
\hline 309100 & 309797 & 40 & 9 \\
\hline 322794 & 332134 & 40 & 5 \\
\hline 324812 & 323434 & 42 & 8 \\
\hline 339820 & 336448 & 45 & 9 \\
\hline 358253 & 364304 & 48 & 9 \\
\hline 364397 & 377275 & 49 & 9 \\
\hline 382829 & 402416 & 52 & 9 \\
\hline 433387 & 413387 & 58 & 5 \\
\hline 399152 & 408462 & 58 & 15 \\
\hline 437422 & 469459 & 62 & 11 \\
\hline 498863 & 481703 & 72 & 11 \\
\hline 517295 & 514032 & 75 & 11 \\
\hline 567150 & 528171 & 82 & 9 \\
\hline 550033 & 501138 & 82 & 14 \\
\hline 597871 & 508964 & 87 & 9 \\
\hline 616303 & 513099 & 90 & 9 \\
\hline
\end{tabular}

Źródło: opracowanie własne.

Porównanie oszacowań wartości nieruchomości mieszkaniowych, które znalazły się w próbie, nie daje podstaw do wskazania stałej tendencji którejkolwiek z metod do zawyżania lub zaniżania ceny. Odchylenia oszacowań zarówno w dół, jak i w góre są możliwe do uzyskania w przypadku obu metod. Warto jednak podkreślić, że nawet mało rozbudowany model regresji należy do narzędzi klasycznej ekonometrii, w przypadku którego możliwa jest nie tylko ocena tzw. dopasowania modelu do danych empirycznych, ale również przetestowanie wielu innych własności statystycznych. Ponadto, budując model, staramy się kontrolować sensowność znaków i wartości oszacowań parametrów $\mathrm{z}$ punktu widzenia teorii ekonomicznej lub szerszej wiedzy merytorycznej.

Pomijając własności interpretacyjne modelu regresji, nie sposób nie wspomnieć, że metoda interpolacji Sheparda należy do nieco innej grupy metod aproksymacji funkcji. Jej idea sprowadza sie do wyrażenia poszukiwanej wartości funkcji „,z" dla danego obiektu za pomoca wyrażenia, które przypomina średnią ważoną wartości innych obiektów. Wagi są tutaj tak dobrane, aby malały wraz ze wieszającą się rozbieżnością pomiędzy cechami obiektu lub współrzędnymi w przypadku danych umieszczonych na siatce mapy (x, y). Metoda Sheparda nie daje badaczowi możliwości interpretacji, a jej istotą jest oszacowanie poszukiwanej wartości funkcji. Zawarte w tabeli 2 przykłady oszacowań zdaja sie wskazywać, że wyniki uzyskane dla lokali relatywnie małych i dużych są nieco przeszacowane na podstawie modelu regresji. Różnice są szczególnie duże dla nieruchomości mieszkaniowych o powierzchni powyżej $80 \mathrm{~m}^{2}$. Dla porównania wystarczy podać, że w próbie znalazło się mieszkanie o powierzchni $90 \mathrm{~m}^{2}$, położone w sześcioletnim budynku z ceną ofertową około 540 tys. pln. Szacowanie wartości nieruchomości mieszkaniowych o powierzchni 100 metrów kwadratowych i więcej wymaga uwzględnienia dodatkowych zmiennych, które zazwyczaj korespondują z podwyższonym standardem. Dla ułatwienia porównywalności zastosowany w badaniu model regresji również zawiera dwie zmienne objaśniające (tabela 3 ).

Choć przedstawiony w tabeli 3 model regresji nie jest skomplikowany, to wyjaśnia zmienność ceny mieszkania w 85\% (Dopasowany R kwadrat). Jest to przypadek szczególny, który dotyczy największej dzielnicy Warszawy o relatywnie małym zurbanizowaniu i z niezbyt dogodnym połączeniem komunikacyjnym z centrum. Nabywcy decydujaccy się na zakup mieszkania w tej okolicy zazwyczaj godzą się na dużą odległość od centrum miasta, ponieważ kuszeni są niską ceną za metr kwadratowy. W przypadku Białołęki cena całkowita nieruchomości mieszkaniowej aż w $85 \%$ wyjaśniona została zatem w 2009 roku przez metraż i liczbę lat budynku. Można powiedzieć, że wzrost powierzchni mieszkania o jednostkę $\left(\mathrm{tj} .1 \mathrm{~m}^{2}\right)$ powoduje średnio wzrost jego ceny o 6144.1 pln, przy założeniu ceteris paribus. Jednocześnie wzrost liczby lat 
Tabela 3. Model regresji opisujący cenę nieruchomości mieszkaniowej dla dzielnicy Białołęka w roku 2009

\begin{tabular}{|c|c|c|c|c|}
\hline \multicolumn{2}{|c|}{ Statystyki regresji } & & & \\
\hline Wielokrotność R & 0,92 & & & \\
\hline $\mathrm{R}^{2}$ & 0,85 & & & \\
\hline Dopasowany $\mathbf{R}^{2}$ & 0,85 & & & \\
\hline $\begin{array}{l}\text { Błąd standardowy składnika } \\
\text { resztowego }\end{array}$ & 37311,33 & & & \\
\hline \multirow{3}{*}{$\begin{array}{l}\text { Liczba oserwacji } \\
\text { ANALIZA WARIANCJI }\end{array}$} & 72,00 & & & \\
\hline & & & & \\
\hline & $d f$ & $S S$ & $M S$ & $F$ \\
\hline Zmienność wyjaśniona regresją & 2 & 565241737845 & 282620868923 & 203,01 \\
\hline Zmienność resztowa & 69 & 96057348983 & 1392135493 & \\
\hline \multirow[t]{2}{*}{ Zmienność całkowita } & 71 & 661299086828 & & \\
\hline & Wspótczynniki & $\begin{array}{c}\text { Blad } \\
\text { standardowy }\end{array}$ & $\begin{array}{l}\text { Statystyka } \\
\text { t-Studenta }\end{array}$ & $\begin{array}{c}\text { Wartość } \\
p\end{array}$ \\
\hline Stała & 94149,6 & 17898,0 & 5,26 & 0,00 \\
\hline Powierzchnia & 6144,1 & 305,9 & 20,08 & 0,00 \\
\hline Liczba lat & $-3423,5$ & 1034,5 & $-3,31$ & 0,00 \\
\hline
\end{tabular}

Postać analityczną zbudowanego modelu regresji można zapisać:

Cena $_{\mathrm{i}}=94149,6+6144,1 *$ Powierzchnia $_{\mathrm{i}}-3423,5$ Liczba lat $_{\mathrm{i}}$

Źródło: opracowanie własne.

budynku, w którym położone jest mieszkanie o jednostkę (tj. 1 rok) skutkuje średnio zmniejszeniem ceny całkowitej mieszkania o 3423.5 pln ceteris paribus. Stąd naturalna wydaje się tendencja do utraty wartości nieruchomości mieszkaniowej wraz z upływem czasu. Co ciekawe, nie jest to tendencja oczywista dla wszystkich dzielnic stolicy. Istnieją obszary, zwłaszcza położone w ścisłym centrum miasta, gdzie mieszkania starsze sa generalnie droższe od pozostałych. Może to być związane z lepszą lokalizacją, większą kubaturą lub modą na rynku związaną z nabywaniem mieszkań w określonym stylu. Białołęka jest jednak na tyle typową i młodą dzielnicą Warszawy, że nie podlega wyrafinowanym zależnościom, które traktować należy jako ciekawostki występujące na rynku śródmiejskim. Znaki oszacowań parametrów należy uznać zatem za poprawne. Odchylenie standardowe składnika resztowego $\mathrm{w}$ modelu wyniosło 37311,33 pln, czyli przeciętne odchylenie ceny teoretycznej o empirycznej mieszkania na Białołęce wynosi w badaniu ponad 37 tys. pln. Porównując tą wartość ze średnią arytmetyczną ceny dla całego zakresu próby 383701,90 pln (tabela 1), otrzymujemy współczynnik zmienności resztowej poniżej $10 \%$, co jest wartością błędu dość niską w badaniach empirycznych (Gajda, 2004). Dla zapewnienia większej wiarygodności obliczeń model regresji został oszacowany również w programie ekonometrycznym Eviews, który potwierdził uzyskane wcześniej wyniki. Tabela 4 zawiera zestawienie wartości teoretycznych, empirycznych i składnika resztowego w badanym zakresie 72 obserwacji próby.

Przedstawiony model wykazuje rozkład zakłóceń zgodny z rozkładem normalnym na podstawie testu Jarque-Bera. Test White'a w programie Eviews wzbudził jednak podejrzenie występowania heteroskedastyczności składnika resztowego, co jest częstym zjawiskiem w przypadku danych przekrojowych (Gajda, 2004). Z tego powodu model został oszacowany ponownie z wykorzystaniem metody odpornej Newey-Westa (Maddala, 2006). Wynik oszacowania odpornego nie spowodował jednak znaczących zmian ocen parametrów lub statystyki t-Studenta. Szczegółowe wyniki estymacji 
Tabela 4. Wartości empiryczne, teoretyczne i składniki resztowe modelu.

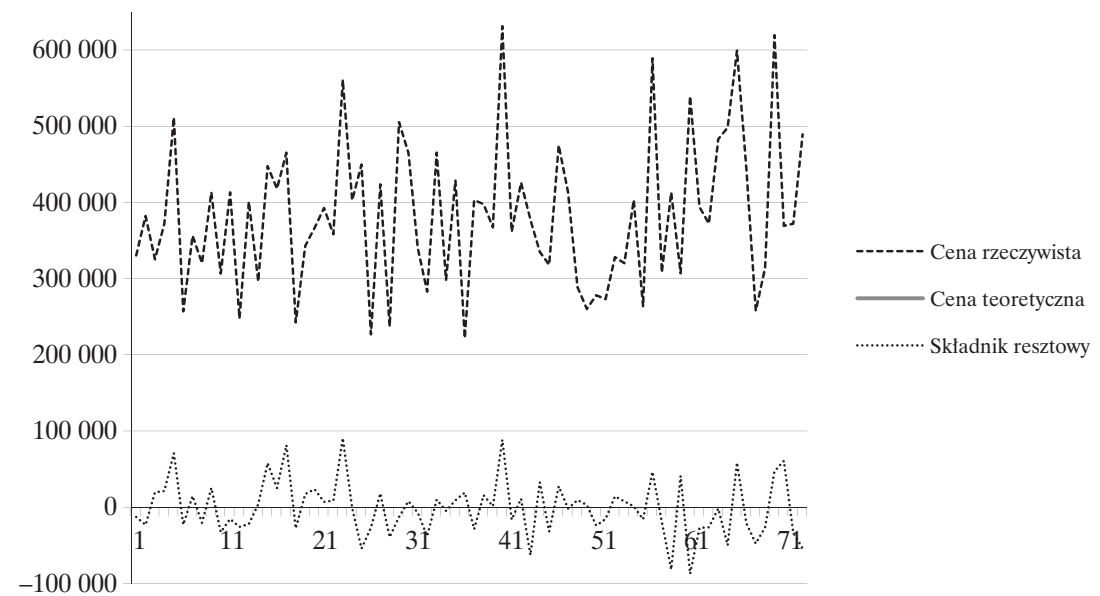

Źródło: opracowanie własne.

nie zostały przedstawione $\mathrm{w}$ niniejszym opracowaniu, ponieważ jego istota koncentruje się na zastosowaniu metody interpolacji Sheparda do szacowania nieruchomości mieszkaniowych. Natomiast model regresji został przytoczony jedynie jako alternatywne i dość dobrze znane narzędzie wspomagania wyceny, które stanowi punkt odniesienia w celu dokonywania porównań obu metod. Z przeprowadzonego porównania można wnioskować, że nawet w uproszczonym przypadku modelowania ceny dla dzielnicy Białoleka metoda Sheparda lepiej od regresji odzwierciedla zmienność wartości dla lokali najmniejszych i największych w próbie. Choć jednocześnie interpolacja odznacza się brakiem mechanizmów oceny uzyskanych wyników i interpretacji.

\section{Zakończenie}

Rynek nieruchomości w USA ukazuje powszechne zastosowania narzędzi zautomatyzowanej wyceny. Wiele $\mathrm{z}$ nich jest opartych właśnie na metodzie interpolacji Sheparda w wersji wielowymiarowej. Narzędzia te są mocno krytykowane przez rzeczoznawców majątkowych, których wyceny są drogie (Harney, 2007). W Polsce dodatkowo Ustawa o gospodarce nieruchomościami z dnia 21 sierpnia 1997 roku rezerwuje w wielu przypadkach szacowanie wartości nieruchomości dla licencjonowanych rzeczoznawców majątkowych. Są to ludzie o należytych kwalifikacjach zawodowych i doświadczeniu. Pomimo zapowiadanej wcześniej deregulacji, wiele zawodów regulowanych zostało utrzymanych z mocy obowiązującego prawa. Zastosowań wszelkiego typu „kalkulatorów” zwanych narzędziami zautomatyzowanej wyceny można zatem szukać w obszarach nieprofesjonalnych szacunków lub na polu narzędzi wspomagających wycenę dokonywaną przez ekspertów. Rynek nieruchomości podlega zmianom, które często są nieregularne, stąd przewidywanie i ocena procesów zachodzących na nim jest trudne a czasami nawet niemożliwe. Ze statystycznego punktu widzenia jest to źródłem trudności w modelowaniu na szczeblu makroekonomicznym. Podobnie wygląda kwestia wyceny pojedynczego mieszkania, które posiadać może wiele nietypowych cech i własności o naturze fizycznej bądź prawnej. Dodatkowo różne mogą być okresy sporządzanej wyceny, upływ czasu i stan gospodarki to czynniki, które sprawiają, że oszacowanie wartości może być w praktyce mniej lub bardziej precyzyjne. W zasadzie trudno jest mówić o dokładności wyceny, ponieważ jest ona podobna do prognozowania w skali mikroekonomicznej. Tak naprawdę dopiero ostateczny nabywca decyduje o wartości rynkowej danej nieruchomości, jeśli jest on w stanie za nią zapłacić określoną cenę. $\mathrm{Z}$ punktu widzenia warunków zewnętrznych wydaje się że wycena podobnie jak prognozowanie jest możliwa i prowadzi do zadowalających pod względem precyzji oszacowań w warunkach stabilności gospodarczej i dostępności do 
aktualnych informacji rynkowych. W okresach dotkliwych kryzysów, gdy ceny szybko się zmieniają lub ilość transakcji na rynku jest niewielka, trudno jest dokonać szacunków i to bez względu na to czy autorem wyniku jest człowiek czy algorytm matematyczny. Dlatego w praktyce wartość wyceny nie jest jednakowa i zależy od eksperta, który podejmuje się oszacowania. Natomiast rzetelność jego pracy jest oceniana nie pod kątem odchyleń wyniku od faktycznej ceny transakcyjnej, która została uzyskana za daną nieruchomość, lecz pod kątem logiczności przeprowadzonego rozumowania.

Autor niniejszego opracowania prowadził już wcześniej badania związane z wykorzystaniem modeli ekonometrycznych do opisu zmienności cen nieruchomości mieszkaniowych w Warszawie. Badania dotyczyły różnych dzielnic i okresów - zarówno dobrej, jak i złej koniunktury gospodarczej. W szczególności budowane modele oparte były na klasycznej regresji liniowej i nieliniowej oraz podejściu panelowym z efektami ustalonymi. Obserwacje autora dotyczące przydatności metody interpolacji Sheparda do problemu wyceny nieruchomości w znaczącym stopniu są zbieżne $\mathrm{z}$ wnioskami płynącymi z wcześniejszych badań, które wykorzystywały narzędzia typowo ekonometryczne.

W praktycznych zastosowaniach łatwo jest wyszukać przykłady, które zaprzeczają przydatności wyceny automatycznej. Weźmy pod uwage problem oszacowania wartości dwóch z pozoru podobnych lokali położonych na tej samej ulicy. Załóżmy, że pierwszy będzie zaniedbany, ale usytuowany przy parku. Natomiast drugi zadbany, lecz w sąsiedztwie hałaśliwej ulicy lub zacisznego cmentarza. Prawdopodobnie szacując wartość w sposób automatyczny, nie będziemy w stanie uwzględnić szczegółowej lokalizacji, która w rzeczywistości powinna wziąć górę nad stanem fizycznym lokalu. W tej sytuacji przypominamy sobie, co w potocznym żargonie rzeczoznawców kształtuje cene nieruchomości - „lokalizacja, lokalizacja i lokalizacja...”. Niestety narzedzia zautomatyzowanej wyceny zazwyczaj nie uwzględniają wpływu bardzo szczegółowej lokalizacji na wartość szacowanego obiektu. Należy jednak podkreślić, że wraz z wirtualizacją świata i rozwojem GPS-u stopień niedokładności odzwier- ciedlenia położenia geograficznego przez formuły analizy numerycznej staje się coraz mniejszy. Z pewnościa w obecnym czasie jedynie bardzo rozwinięte gospodarczo i nowoczesne gospodarki stać na tworzenie systemów monitorowania zmian wartości w przestrzeni geograficznej. Zwłaszcza, że wartość ulega przeobrażeniom w czasie wraz $\mathrm{z}$ postepujacym procesem urbanizacyjnym i zmieniajacym się otoczeniem. W Warszawie np. wiele lokalizacji zyskało na znaczeniu, gdy uruchomiono nową linię metra, a nawet już wcześniej przy ogłoszeniu planów jej budowy. Choć łatwo jest wymienić przykłady nieruchomości, dla których zastosowanie tzw. kalkulatorów wyceny jest pozbawione sensu, to równie szybko można wyróżnić obszary, w których wycena automatyczna działa wystarczająco skutecznie. Na ogół takim szacunkom trafnie poddają się nieruchomości zaliczane do typowych, zwłaszcza przy występowaniu dużej płynności rynku. Równie istotny jest tutaj brak przejściowych szoków lokalnych bądź makroekonomicznych oraz dostępność aktualnych informacji związanych z najbliższą okolicą nieruchomości.

Praktycznym problemem jest także zakres próby, który należy włączyć do badania - podobnie jak rzeczoznawca majątkowy zastanawia się nad liczbą obiektów niezbędnych do wykonania porównań (Cymerman i Hopfer, 1999). W podejściu bazującym na metodzie Sheparda zakres próby ma istotne znaczenie. Choć w części empirycznej skorzystano z bazy danych dla dzielnicy Białołęka, to $\mathrm{w}$ praktyce autor chetnie zawęiłby obszar dokonywanych szacunków pod warunkiem dostępności do odpowiednich danych liczbowych. W praktycznym wykorzystaniu algorytmów wyceny automatycznej liczy się nie tylko ilość posiadanych danych, ale również ich jakość i bliskość do wycenianego obiektu.

Narzędzi zautomatyzowanej wyceny w obecnym świecie nie można nazwać całkowicie niepotrzebnymi, zwłaszcza że wraz w eksplozją technologii IT ich dokładność najprawdopodobniej będzie rosła. Stosując narzędzia ilościowe, które wspomagaja wycene nieruchomości, z pewnościa trzeba znać ich wady i zalety. Przykłady z rynku USA pokazują, że wyceny automatyczne mogą być skuteczne, szybkie i tanie, a dodatkowo latwo dostepne przez Internet. Ponadto ich zaletą jest brak subiekty- 
wizmu, który sprawia, że wycena tej samej nieruchomości w tym samym czasie skutkuje otrzymaniem takiego samego wyniku oszacowania.

\section{Bibliografia}

Baranowski, L. (2009). Największe wzięcie mają najmniejsze mieszkania. Rzeczypospolita.

Borkowski, B., Dudek, H. i Szczesny, W. (2007)

Ekonometria, wybrane zagadnienia. Warszawa: Wydawnictwo Naukowe PWN.

Cymerman, R. i Hopfer, A. (1999). System i procedury szacowania nieruchomości. Olsztyn - Zielona Góra: Zachodnie Centrum Organizacji.

Dydenko, J. (2012). Szacowanie nieruchomości. Warszawa: Wolters Kluwer Polska.

Fortuna, Z., Macukow, B. i Wąsowski, J. (2001). Metody numeryczne. Warszawa: WNT.

Gajda, J. (2004). Ekonometria. Warszawa: C.H. Beck.

Garcia, N., Gamez, M. i Alfaro, E. (2008) ANN+GIS: An automated system for property valuation. Albacete: Neurocomputing.
Gordon, W. i Wixom, J. (1978). Shepard's Method of Metric Interpolation to Bivariate and Multivariate Interpolation. Mathematics of computation, 32(141), http://dx.doi.org/10.2307/2006273.

Harney, K. (2007). Reprisals on Appraisals. Washington Post.

Kincaid, D. i Cheney, W. (2002). Analiza Numeryczna. Warszawa: WNT.

Maddala, G.S. (2006). Ekonometria. Warszawa: PWN.

Nurek, W. (2004). Rola baz danych w procesie wyceny nieruchomości. Nieruchomości, 5(69).

O’Neill, J. (2004). An automated valuation model for hotels. Cornell Hotel and Restaurant Administration Quarterly.

Shepard, D. (1968). A two-dimensional interpolation function for irregularly-spaced data. New York: ACM Proceedings of the 23rd ACM national conference, http://dx.doi.org/10.1145/800186.810616.

Shiller, R. i Weiss, A. (1999). Evaluating Real Estate Valuation Systems. The Journal of Real Estate Finance and Economics.

Żak, M. (2013). Wycena nieruchomości. Warszawa: C.H. Beck. 